\title{
Knowledge on tuberculosis among students of higher secondary school, lalitpur, Nepal
}

\begin{abstract}
The descriptive study conducted to assess the knowledge on tuberculosis among students of higher secondary school, Lalitpur, Nepal was carried out utilizing non-probability purposive sampling technique among +2 students.

The analysis of the data revealed that all the respondents had little knowledge about tuberculosis. Among those, $92 \%$ respondents got information from media and teachers, $90 \%$ respondents received from newspaper and health-worker. Majority of the respondents $(80 \%)$ said that tuberculosis is the communicable bacterial diseases whereas $12 \%$ said that it is hereditary diseases, majority of the respondents $(80 \%)$ said that bacteria are the causative organism of the tuberculosis. The entire respondent knew that TB is curable disease but they lack knowledge about diagnostic feature of TB and DOTS treatment therapy and its duration. In regard to the detection of the tuberculosis, majority (94\%) of the respondents said sputum test and chest X-ray help to detect tuberculosis, $90 \%$ said on the basis of sign and symptoms. Only 10\% respondents had heard about mountex test. Among them, $40 \%$ said skin is taken as the sample unit for mountex test as well as $20(40 \%)$ said that blood as sample. More than two third (78\%) knew that the patients should not be admitted in hospital to receive treatment. More than half $(56 \%)$ had heard about DOTS for the treatment of tuberculosis. Among those, 28\% knew that DOTS is taken for 6-8 months. In the nut shell, knowledge on TB among students of higher secondary school should be promoted through enhancement of relevant health education. The knowledge should be raised through media, various awareness programs through involvement of parents, teachers and health personnel. Proper knowledge about tuberculosis will provoke a way to prevent the spread and management of TB through proper treatment in this developing world.
\end{abstract}

Keywords: tuberculosis, higher secondary school student, awareness, prevention of TB, plaguing, mycobacterium

\author{
Volume 4 Issue 5 - 2016
}

\author{
Bijay Kumar Sah,' Jay Prakash Sah,, ${ }^{2,4}$ Sanjeev \\ Kumar Shah, ${ }^{3}$ Amita KCl \\ 'Department of Public Health, Hope International College \\ affiliated to Purbanchal University, Nepal \\ 2Soonchunhyang Institute of Medi-bio Science (SIMS) \\ Soonchunhyang University, Asan-Si, South Korea \\ ${ }^{3}$ Department of Public Health, Nitte University, India \\ ${ }^{4}$ Department of Medical Laboratory Science, Pokhara University, \\ Nepal
}

Correspondence: Jay Prakash Sah, Soonchynhyang Institute of Medi-bio Science, The School of Medicine, Soonchynhyang University, SIMS- 25, Dongnam-gu, South Korea,Tel +820102768I729, Email shahjayprakash I@gmail.com

Received: March 31, 2016 | Published: May 24, 2016

\section{Introduction}

Tuberculosis is an infectious disease caused by the bacterium Mycobacterium tuberculosis, which generally affects the lungs, but can also affect other parts of the body. Most infections are as asymptomatic latent tuberculosis, of which about $10 \%$ of latent infections progress to the active disease. ${ }^{1}$ It has been probably recognized since Stone Age. The traces of tuberculosis lesions have been found in skull and spines of Egyptian mummies, tell us that TB has been plaguing humans for at least 4000years. ${ }^{2}$ Now-adays due to many great technological development like invention of streptomycin, sulfonamide, Para-amino-salicylic acid, ionized, BCG vaccine, tuberculin and anti tubercular drugs; implementation of principle of national TB control program as well as directly observed treatment short course (DOTS) have been easily available in all over the world. However, TB is still the leading infectious cause of morbidity and mortality among adults and has claimed the lives of more than 200millions peoples since $1882 .^{3,4}$

Globally, tuberculosis is a threat with nearly two billion people (one third of the world's population) harboring latent infection. Based on surveillance and survey data, WHO estimates that 9.27 million new cases of TB occurred in 2012 (139 per 100000 population), while in 2006, 9.24million new cases (140/100000) was diagnosed. Among 9.27 million new cases, an estimated $44 \%$ or 4.1 million (61 per 100000 population) were new smear positive cases. ${ }^{5}$ There were an estimated 13.7million prevalent cases in 2013 (206 per 100000 population), a slight decrease from 2012.
Similarly mortality rate of TB is 1.32 millions populations in 2013 . Asia (south-east Asia and Western pacific regions) accounts of 55\% of global cases. Twenty two high burden countries (HBCs) collectively account for $80 \%$ of TB cases globally. Countries in the south-east Asia region have to make steady progress of TB control. The region still account for the highest number of TB patient globally, carrying over $34 \%$ of the worlds TB burden. The south-east Asia region, with an estimated 4.88 million prevent cases and annual incidence of 3.17 million TB cases, carries one third of the global burden of TB. Five of the 11 member countries in the region are among the 22 highburden countries. The SAARC region, with an estimated 4.4million prevalent cases and an annual incidence of 2.7 million TB cases, carries $29.3 \%$ of the global burden of TB. Four of the eight member countries in this region are among the 22 high burden countries. The disease still claims more than four lakhs lives each year. ${ }^{7}$

In contest of Nepal, Tuberculosis remains one of the major public health problems. About $45 \%$ population is infected with TB, of which $60 \%$ are adult. Nepal with an annual estimated 240 per 0.1 million population (67546) prevalent cases and incidents of 173 per 0.1 million population (48766) TB cases. The mortality due to TB estimated is 23 per 0.1 million of all forms of TB. ${ }^{7}$ According to DOHS, in Lalitpur district, the cases finding rate of tuberculosis was found to be $57 \%$ in 2013 . Every year 40000 people develop active TB, among them 20 thousand have infectious pulmonary disease. Treatment by DOTS has reduced the number of deaths; however five thousand to 7 thousand people still die per year from TB even though DOTS have been successfully implemented throughout. Nepal co-ordinates with 
the private sector, local government bodies, NGOs, Social workers, education sectors and other sectors of the society in order to expand DOTS and sustain the significant results achieved by NTP (National Tuberculosis Program). By 16th July 2008 DOTS has been expanded to 1079 treatment centre with 3147 sub centre. The treatment success rate stands at 88.1 percent and case finding rate of 71.39 percent. At the national level 33,419 TB patients have been registered, among them 14,640 infectious are being treated under the DOTS strategy in NTP during the FY 2012/13. ${ }^{7,8}$

Even after 50years of the introduction of effective chemotherapy, TB still remains the biggest killer of young people, women and children in world. SAARC TB control program in Nepal has also emphasized in public awareness and advocacy program on TB and HIV/ AIDS though school (teacher/ student), media, medical colleges and NGOs of Nepal.?

TB has also been encountered in children of school going ages. School children and the women are the more vulnerable groups susceptible to TB infections. TB control program also planned to create awareness about TB through the active participation of school and school students. Tuberculosis has also been included in the curriculum of the school children of class nine and ten with a view to impart knowledge on TB.

Hence this study is planned to assess the knowledge on tuberculosis among all school going students of developing countries like Nepal. The use of various sources of information to impart knowledge about tuberculosis like Medias, health personnel, teachers, family members are useful to prevent spreads of TB. Similarly, developments of necessary materials in increasing student's knowledge about TB, emphasis of knowledge regarding tuberculosis in syllabi of school students should be a tool to prevent and manage tuberculosis, and to reduce the mortality and morbidity rates in the country.

\section{Material and methods}

A descriptive, questionnaire based study was adopted to assess the knowledge regarding tuberculosis among college students especially $10+2$ students of white House college, khumaltar, satdobato, Lalitpur, Nepal in the duration of 6 months from 1st October 2014 to April 2015. We studied various independent variables like age of respondents, education level of parents, source of information, availability of health services, environment etc. The sampling technique used here is based on non-probability convenient sampling by selecting 50 students from each section of class $10+2$ for the study.

In order to measure the research variable, a semi-structured questionnaire was designed in english medium. The questionnaire consisted of four parts;

a. Part1: socio-demographic information

b. Part 2: questions related to knowledge on TB as per objectives

c. Part 3: questions related to the preventive measures for TB

d. Part 4: questions related to the treatment of TB

We explained about the research and its objective and questions to respondents and then the questionnaire was distributed to the participants giving them 45 minutes to fill the questionnaire.

\section{Ethical consideration}

Written and verbal informed consent was taken from Ethical
Committee of Hope International College, Satodobato, Lalitpur, Nepal and anonymity of the participants was maintained. Confidentiality of data was ensured. Written consent from Director of white House College for conducting data collection was also taken to collect data.

\section{Data analysis}

The data collected were entered in Microsoft excel 2007 and analyzed by SPSS 15 .

\section{Result}

This primary data collected from the self administered questionnaire and the subsequent inference drawn from them. The data have been arranged orderly in the concise and logical order to facilitate interpretation.

The Table 1 reveals that more than half $(58 \%)$ of the respondents were male and $42 \%$ were female. Concerning the age of the respondents, half of the respondents were at 15years of age where as $46 \%$ respondents were at 16 years and $4 \%$ only were at 14 years. The mean age of the respondent's was 15.42 years. Regarding religion of the respondents, majority (96\%) of the respondents were Hindu whereas $2 \%$ were Buddhist and $2 \%$ of the respondents were Christian. Among the respondents regarding their caste, nearly half (48\%) of the respondents were Newar, $32 \%$ of the respondents were Chhetri, $16 \%$ were Brahmin and 4 were Rai.

Table I Personal information of the respondents

\begin{tabular}{|c|c|c|}
\hline Characteristics & Number & Percentage (\%) \\
\hline \multicolumn{3}{|l|}{ Sex } \\
\hline Male & 29 & 58 \\
\hline Female & 21 & 42 \\
\hline \multicolumn{3}{|l|}{ Age } \\
\hline 14 years old & 2 & 4 \\
\hline 15 years old & 25 & 50 \\
\hline 16 years old & 23 & 46 \\
\hline \multicolumn{3}{|l|}{ Religion } \\
\hline Hindu & 48 & 96 \\
\hline Christian & I & 2 \\
\hline Buddhist & I & 2 \\
\hline \multicolumn{3}{|l|}{ Ethnicity } \\
\hline Brahmin & 8 & 16 \\
\hline Chhetri & 24 & 48 \\
\hline Newar & 16 & 32 \\
\hline Others & 2 & 4 \\
\hline
\end{tabular}


The Table 2 shows that more than three fourth $(78 \%)$ of the respondents were living in nuclear family, followed by joint family $(20 \%)$ and extended family $(4 \%)$. Concerning the number of family members, more than half $(58 \%)$ of the respondents had family members ranging 1-4 where as $40 \%$ had members ranging 5-8 and $2 \%$ had the number of family members above 8 .

Table 2 Family background of the respondents

\begin{tabular}{lll}
\hline Characteristics & Number & Percentage \\
\hline Family Status & & \\
\hline Nuclear family & 39 & 78 \\
Joint family & 10 & 20 \\
Extended family & 1 & 2 \\
\hline Family Range & Number of family members \\
\hline 1-4 & 20 & 40 \\
$5-8$ & 29 & 58 \\
8 and above & 1 & 2 \\
\hline
\end{tabular}

The Table 3 shows that majorities (94\%) of the fathers were literate and $6 \%$ were illiterate. Among them, about half $(52 \%)$ of the fathers of the respondents had secondary level education and only $8 \%$ had master's level education. Among the literate mothers $(n=32)$, less than three fourth $(72 \%)$ had secondary level education and $3 \%$ of mothers had bachelor's and master's level education.

Table 3 Education Status of the Parents

\begin{tabular}{lll}
\hline Characteristics & Number & Percentage \\
\hline Education Level of Father & & \\
\hline Illiterate & 3 & 6 \\
Literate & 47 & 94 \\
Secondary level & 26 & 52 \\
Higher Secondary level & 13 & 26 \\
Bachelor's lever & 4 & 8 \\
Master's level & 4 & 8 \\
\hline Education Level of Mothers & \\
\hline Illiterate & 18 & 36 \\
Literate & 32 & 64 \\
Primary level & 3 & 6 \\
Secondary level & 23 & 46 \\
Higher Secondary level & 4 & 8 \\
Bachelor's level & 1 & 2 \\
Master's level & 1 & 2 \\
\hline
\end{tabular}

The Table 4 shows that the occupation of the fathers of the respondents in which they were engaged. It shows that half $(50 \%)$ of the fathers were engaged in service, rest were in business, agriculture, driving, guard. Majorities (88\%) were found to be housewives and rests were engaged in service, business and agriculture.
Table 4 Occupation of Parents

\begin{tabular}{lcc}
\hline Characteristics & Number & Percentage \\
\hline Occupation of Father & \\
\hline Agriculture & 10 & 20 \\
Business & 10 & 20 \\
Daily wages & 25 & 50 \\
Others & 5 & 10 \\
\hline Occupation of Mother & \\
\hline Agriculture & 4 & 8 \\
Business & 2 & 4 \\
Service & 4 & 8 \\
Housewife & 39 & 78 \\
Others & 1 & 2
\end{tabular}

The Table 5 shows that nearly three fourth $(74 \%)$ of the respondents had room ranging $5-8,14 \%$ had rooms $1-14$ whereas $12 \%$ had rooms more than 8 . In regards to the types of fuel used by the respondents for cooking, majority ( $88 \%$ ) used liquefied petroleum gas, $14 \%$ used chulo (firewood), $8 \%$ used stove (kerosene oil) and $2 \%$ used biogas for cooking.

Table 5 Housing environment of the respondent

\begin{tabular}{lll}
\hline Characteristics & Number & Percentage \\
\hline Number of Rooms Used & & \\
\hline I-4 & 7 & 14 \\
$5-8$ & 37 & 74 \\
8 and above & 6 & 12 \\
\hline Types of Fuel Used & & \\
\hline Liquid field petroleum gas & 44 & 88 \\
Stove (kerosene oil) & 4 & 8 \\
Chulo (firewood) & 7 & 14 \\
Others & 1 & 2 \\
\hline
\end{tabular}


The Table 6 shows that all of the respondents had knowledge that smoke predisposes tuberculosis. Among the respondents, majority (98\%) of the respondents had knowledge that smoking by self and smoking by others can predispose tuberculosis.

Table 6 Housing Condition of the Respondents

\begin{tabular}{|c|c|c|}
\hline Characteristics & Number & Percentage \\
\hline \multicolumn{3}{|c|}{ Smoke Predisposes Tuberculosis } \\
\hline Yes & 50 & 100 \\
\hline No & 0 & 0 \\
\hline \multicolumn{3}{|c|}{ IfYes, Smoke Types which Predispose Tuberculosis } \\
\hline \multicolumn{3}{|l|}{ Smoking by Self } \\
\hline Yes & 49 & 98 \\
\hline No & I & 2 \\
\hline \multicolumn{3}{|c|}{ Smoking by Others } \\
\hline Yes & I8-Feb & 98 \\
\hline No & 1 & 2 \\
\hline \multicolumn{3}{|c|}{ Smoke from Firewood } \\
\hline Yes & 34 & 68 \\
\hline No & 16 & 32 \\
\hline
\end{tabular}

The Table 7 reveals that all of the respondents had heard about tuberculosis. Among those, $46(92 \%)$ respondents got information from media and teachers, $45(90 \%)$ respondents received from newspaper and health -worker, $40(80 \%)$ from family members and $31(62 \%)$ received from friends.

Table 7 Source of Information about TB

\begin{tabular}{|c|c|c|}
\hline Characteristics & Number & Percentage \\
\hline \multicolumn{3}{|c|}{ Heard about Tuberculosis } \\
\hline Yes & 50 & 100 \\
\hline \multicolumn{3}{|c|}{ If yes, Source of Information } \\
\hline Media & 46 & 92 \\
\hline Newspaper & 45 & 90 \\
\hline Friends & 31 & 62 \\
\hline Family members & 40 & 80 \\
\hline Teacher & 46 & 92 \\
\hline Health workers & 45 & 90 \\
\hline
\end{tabular}

The Table 8 reveals that majority ( $88 \%$ ) of the respondents said that tuberculosis is the communicable bacterial disease whereas 20 $(40 \%)$ said that it is the disease due to smoking and alcohol, $69(12 \%)$ said that it is hereditary disease. Majority $(84 \%)$ of the respondents said that bacteria is the causative organism of the tuberculosis whereas $10(20 \%)$ of respondents said that it is caused due to virus.

Table 8 Type of Disease

\begin{tabular}{|c|c|c|}
\hline Characteristics & Number $(n=50)$ & Percentage \\
\hline \multicolumn{3}{|l|}{ Tuberculosis is } \\
\hline Communicable bacterial disease & 44 & 88 \\
\hline Disease due to smoking and alcohol & 20 & 40 \\
\hline Hereditary disease & 6 & 12 \\
\hline \multicolumn{3}{|c|}{ Causative Organism of Tuberculosis } \\
\hline Bacteria & 42 & 84 \\
\hline Virus & 10 & 20 \\
\hline Parasites & I & 2 \\
\hline \multicolumn{3}{|c|}{$\begin{array}{l}\text { The Table } 9 \text { shows that more than three fourth }(78 \%) \text { said that } \\
\text { does not only affect lungs whereas } 11(22 \%) \text { said that it only affect } \\
\text { ungs. Less than half }(42 \%) \text { of the respondents knew about pulmonar } \\
\text { uberculosis, } 16(32 \%) \text { knew abdominal tuberculosis, } 8(16 \%) \text { of th } \\
\text { espondents knew about bone tuberculosis. No one had been affecte } \\
\text { oy tuberculosis yet. }\end{array}$} \\
\hline
\end{tabular}

Table 9 Type of Tuberculosis

\begin{tabular}{|c|c|c|}
\hline Characteristics & Number & Percentage \\
\hline \multicolumn{3}{|c|}{ Tuberculosis Affects only Lungs } \\
\hline Yes & II & 22 \\
\hline No & 39 & 78 \\
\hline
\end{tabular}

\section{Types of Tuberculosis}

Pulmonary tuberculosis

Abdominal tuberculosis

Bone tuberculosis

Others

Ever affected by it

\begin{tabular}{lll}
\hline No & 50 & 100 \\
\hline
\end{tabular}


The Table 10 shows that all of the respondents knew that smoking is the risk factor of tuberculosis, almost all $(98 \%)$ of the respondent knew that infected person are the risk factors of tuberculosis, 41 $(82 \%)$ thought that poor sanitation is the risk factor for tuberculosis and $7(14 \%)$ thought overwork as risk factor.

Table 10 Knowledge about risk factor of tuberculosis

\begin{tabular}{lcc}
\hline Characteristics & \multicolumn{2}{l}{ Number } \\
\hline \multicolumn{2}{l}{ Risk Factors of Tuberculosis } \\
\hline Through infected person & 49 & 98 \\
Overwork & 7 & 14 \\
Lack of sanitation & 41 & 82 \\
Smoking & 50 & 100 \\
\hline
\end{tabular}

The Table 11 shows that in regard to the spread of tuberculosis, majority $(96 \%)$ of the respondents knew that it is spread through infected air droplets, more than three forth $(76 \%)$ said through sharing, $36(72 \%)$ said through food and water, 32 (64\%) through overcrowding and $12(24 \%)$ said through bad spirits.

Table I I Knowledge about route of transmission

\begin{tabular}{lcc}
\hline Characteristics & Number & Percentage \\
\hline Route of Transmission & & \\
\hline Infected air droplets & 48 & 96 \\
Food and water borne & 36 & 72 \\
Sharing Pates & 38 & 76 \\
Due to bad spirits & 12 & 24 \\
Overcrowding & 32 & 74
\end{tabular}

The Table 12 reveals regarding modes of transmission of the tuberculosis, majority $(82 \%)$ said through infected patient and 39 (78\%) said from pregnant mothers.

Table 12 Knowledge about modes of transmission

\begin{tabular}{lcc}
\hline Characteristics & Number & Percentage \\
\hline Modes of Transmission & & \\
\hline Living with TB infected persons & 41 & 82 \\
Sharing foods & 30 & 60 \\
Sharing utensils & 37 & 74 \\
From pregnant mothers to baby & 39 & 78 \\
Others & 2 & 4 \\
\hline
\end{tabular}

The Table 13 shows concerning the sign and symptoms, almost all (98\%) said that chest pain, cough more than 2 weeks is the sign and symptoms, 47 (94\%) said weight loss, loss of appetite, 45 (90\%) said fever at night and night sweat, tiredness, blood in sputum each and $44(88 \%)$ said that 2 or more than 2 weeks fever is the sign and symptoms.

Table 13 Knowledge about signs and symptoms of tuberculosis

Characteristics Number Percentage

\section{Signs and Symptoms of Tuberculosis}

2 or more than 2 weeks fever

$44 \quad 88$

Fever at night

45

90

Chest pain, cough more than two weeks

49

98

Weight loss, loss of appetite

47

94

Night sweat, tiredness, blood in sputum

45

90

The Table 14 shows that majority (96\%) of the respondents said smokers are in risk of developing tuberculosis whereas $45(90 \%)$ said family and the person close to infected person, more than half (54\%) said that people with HIV/ AIDS, 23 (46\%) said elderly and malnourished people, $22(44 \%)$ said that people working at TB treatment centre had risk of developing tuberculosis.

Table I 4 Knowledge about risk of developing tuberculosis

Characteristics Number Percentage

\section{Risk of Developing Tuberculosis}

Family and person in close contact to patient. 45

90

Elderly

$23 \quad 46$

People with HIV/ AIDS

School Children

15

30

Smokers

48

96

Malnourished people

People working at TB treatment center

22

44

People who are not in contact with TB patient 
The Table 15 reveals in regard to the detection of the tuberculosis, majority (94\%) of the respondents said that sputum test and chest X-ray helps to detect tuberculosis, $45(90 \%)$ said on the basis of sign and symptoms. Only $5(10 \%)$ respondents had heard about mountex test. Among them, $2(40 \%)$ said that skin is taken as the sample unit for mountex test as well as $2(40 \%)$ said blood as sample.

Table 15 Knowledge about diagnostic features of TB

\begin{tabular}{lcc}
\hline Characteristics & Number & Percentage \\
\hline Detection of Tuberculosis & & \\
\hline Sputum test & 47 & 94 \\
Blood test & 38 & 76 \\
Chest X-ray & 47 & 94 \\
Based on sign and symptom & 45 & 90 \\
Mountex test & 14 & 28 \\
\hline Heard about mountex test & & \\
\hline Yes & 5 & 10 \\
No & 45 & 90 \\
\hline If yes, sample for Mountex Test & \\
\hline Skin & 2 & 40 \\
Blood & 2 & 40 \\
Urine & 1 & 20 \\
\hline
\end{tabular}

\section{Knowledge about treatment of tuberculosis}

The Table 16 describes that all (50) of the respondents said that tuberculosis is curable disease. More than two third (78\%) knew the patients should not be admitted in hospital to receive treatment.

Table 16 Knowledge about Curability of Tuberculosis

\begin{tabular}{lll}
\hline Characteristics & Number & Percentage \\
\hline Tuberculosis is & & \\
\hline Curable disease & 50 & 100 \\
Non curable disease & 0 & 0 \\
\hline
\end{tabular}

Patient should be Admitted in Hospital for Treatment

\begin{tabular}{lll}
\hline Yes & 11 & 22 \\
No & 39 & 87 \\
\hline
\end{tabular}

The Table 17 shows that more than half $(56 \%)$ had heard about DOTS for the treatment of tuberculosis. Among those, 14 (28\%) knew that DOTS is taken for 6-8 months. Regarding the availability of antitubercular drugs, $34(68 \%)$ reported that it is found at DOTS center at free of cost and 24 (48\%) said it is found in hospitals at free of cost.

Table 17 Knowledge about DOTS

\begin{tabular}{lcc}
\hline Characteristics & \multicolumn{2}{l}{ Number Percentage } \\
\hline \multicolumn{2}{l}{ Heard about DOTS } \\
\hline Yes & 28 & 56 \\
No & 22 & 44 \\
\hline Duration of treatment by DOTS & \multicolumn{2}{l}{ D } \\
\hline 4-6 months & 6 & 12 \\
6-8 months & 14 & 28 \\
8-10 months & 7 & 14 \\
10-12 months & 1 & 2 \\
\hline
\end{tabular}

\begin{tabular}{lcc}
\multicolumn{3}{l}{ ATT given at free of cost* } \\
\hline Hospitals & 28 & 56 \\
DOTS centre & 34 & 68 \\
Pharmacy & I & 2 \\
\hline
\end{tabular}

The Table 18 shows that about one fourth (26\%) of the respondent reported that DOTS centre is found near to their residence. Among these, nearly half of the respondents mentioned that they reach the DOTS centre within 30 minutes by walking and almost all of the respondents reach within 15 minutes by transportation.

Table I 8 knowledge about availability of DOTS

\begin{tabular}{lcc}
\hline Characteristics & Number & Percentage \\
\hline DOTS Center & Available near the & Residence \\
\hline Yes & 13 & 26 \\
No & 37 & 74 \\
\hline
\end{tabular}

If yes, Time to Reach there by Walking

\begin{tabular}{lll}
\hline $0-15$ minutes & 6 & 46 \\
I5-30 minutes & 6 & 46 \\
30 and more & 1 & 8 \\
\hline
\end{tabular}

By means of Transportation $(n=13)$

\begin{tabular}{lll}
\hline $0-15$ minutes & 12 & 92 \\
$15-30$ minutes & 1 & 8
\end{tabular}


The Table 19 shows that all (50) of the respondents said that it is necessary to complete the full course of treatment. And the respondents were questioned why it is necessary to complete the full course of treatment, all of the respondents said to cure the disease completely, majority (98\%) said to prevent the recurrence of the disease. Similarly, 33(66\%) said to finish the dose prescribed by the doctor and more than half $(56 \%)$ said that it is needed to prevent drug resistance. All $(100 \%)$ of the respondent said to continue medicine with proper diet, almost all (98\%) of the respondent said to go for regular check up.

Table 19 Knowledge about regimen of DOTS

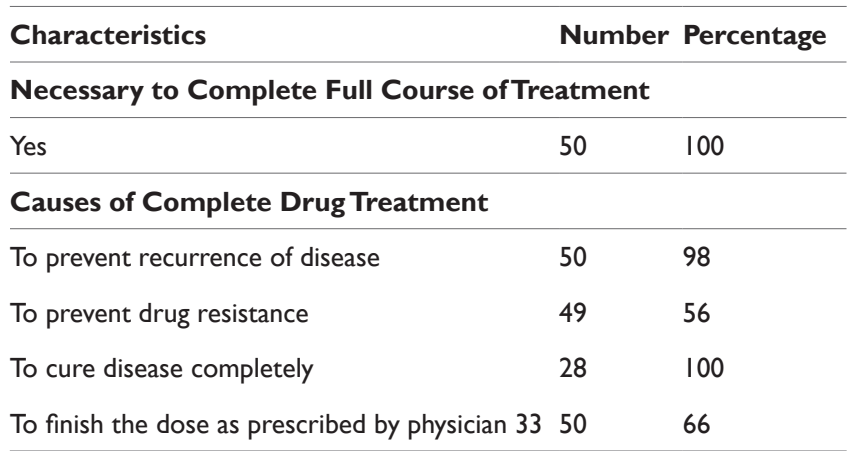

\section{Knowledge about prevention of TB}

The Table 20 shows that all (100\%) of the respondents are faithful on tuberculosis to be prevented. Almost all (96\% knew that there is BCG vaccination against tuberculosis. And majority (92\%) of the respondents had received BCG vaccination. Regarding preventive measures of tuberculosis, almost all (98\%) said that BCG given at birth, majority $(90 \%)$ said identifying infected person and curing by DOTS , $88 \%$ said avoiding sharing utensils used by infected person , $20 \%$ said not living with infected person and $4 \%$ talked about others like avoiding smoking and right disposal of infected sputum.

Table 20 Knowledge about Prevention of Tuberculosis

\begin{tabular}{|c|c|c|}
\hline Characteristics & Number & Percentage \\
\hline \multicolumn{3}{|l|}{ Tuberculosis can be Prevented } \\
\hline Yes & 50 & 100 \\
\hline No & 0 & 0 \\
\hline \multicolumn{3}{|l|}{ Any Vaccination available against Tuberculosis } \\
\hline Yes & 48 & 96 \\
\hline No & 2 & 4 \\
\hline \multicolumn{3}{|l|}{ B.C.G Vaccination } \\
\hline Yes & 46 & 92 \\
\hline No & 4 & 8 \\
\hline \multicolumn{3}{|l|}{ Preventive Measures of Tuberculosis* } \\
\hline B.C.G vaccination at birth. & 49 & 98 \\
\hline Identify the infected person and curing by DOT & 545 & 90 \\
\hline Avoid sharing utensils used by infected person & 44 & 88 \\
\hline Living with the infected person. & 10 & 20 \\
\hline Others (Specify) & 4 & 8 \\
\hline
\end{tabular}

The Table 21 shows that more than half $(52 \%)$ of respondents believes on anti tubercular drugs that do not create side effects and $48 \%$ said that it does have side effects. Among which in regard to the management of anti tubercular drugs, more than half (66\%) said calling health workers at home, $100 \%$ said teaching patients to recognize the sign and symptoms of common side effects of anti tubercular drugs and also visiting nearby health centre and 255 said that wait to heal the side effects.

Table 2 I Knowledge about management of TB

\begin{tabular}{|c|c|c|}
\hline Characteristics & Number & - Percentage \\
\hline \multicolumn{3}{|l|}{ Anti Tubercular drugs create Side Effects } \\
\hline Yes & 24 & 48 \\
\hline No & 26 & 52 \\
\hline \multicolumn{3}{|c|}{ Management of Side Effects of Tuberculosis } \\
\hline Health workers at the home of tuberculosis & 16 & 66 \\
\hline $\begin{array}{l}\text { Teaching patients to recognize symptoms of } \\
\text { Common side effects. }\end{array}$ & 24 & 100 \\
\hline Wait to heal the side effects. & 6 & 25 \\
\hline Visiting nearby health centers. & 24 & 100 \\
\hline
\end{tabular}

The Table 22 reveals concerning the spread of tuberculosis by the patients who are already on effective treatment, more than one third (34\%) said 'yes', 32\% said 'no' and 36\% said 'I don't know'. Likewise, regarding the spread of tuberculosis by the patients who have been cured, nearly three fourth (74\%) said 'No' and 26\% said 'I don't know'.

Table 22 Knowledge about spread to Tuberculosis

\begin{tabular}{lll}
\hline Characteristics & Number & Percentage \\
\hline Treatment & & \\
\hline Yes & 17 & 34 \\
No & 16 & 32 \\
I don't know & 18 & 36 \\
\hline
\end{tabular}

Spread of disease by totally Cured Patients

\begin{tabular}{lcc}
\hline No & 37 & 74 \\
I don't know & 13 & 26 \\
\hline
\end{tabular}

If treatment is stopped in the middle course of the Treatment Period, then*

\begin{tabular}{lcc}
\hline Disease will relapse. & 48 & 96 \\
It will be difficult to treat the disease & 47 & 94 \\
Patient may die & 47 & 94 \\
Happens nothing & 1 & 2
\end{tabular}


Respondents were asked what happens when the treatment is stopped at the middle course of the treatment period, $96 \%$ (48) of the respondents said disease will relapse whereas $96 \%$ said that it will be difficult to treat the disease and similarly $96 \%$ said that patient will die and $2 \%$ said happens nothing.

\section{Discussion}

However, all the respondents have heard about tuberculosis from various sources, among those, 46(92\%) respondents got information from media and teachers, $45(90 \%)$ respondents got information from media and teachers each, $45(90 \%)$ respondents received from newspaper and health-worker, 40(80\%) from family members and $31(62 \%)$ received from friends. The information about tuberculosis received by the respondents from various was not adequate to school students for its prevention and treatment. The study conducted by Tanimawo Mo (1999) also indicated for the avocation and need of health education in college syllabi. ${ }^{9}$

This study showed that the respondents were found to be very much confused about the type of tuberculosis. More than three fourth $(78 \%)$ said that it does not only affect lungs whereas $11(22 \%)$ said that it only affects lungs. Less than half $(42 \%)$ of the respondents knew about pulmonary tuberculosis, 18(36\%) knew abdominal tuberculosis, $8(16 \%)$ of the respondents knew about bone tuberculosis. The knowledge about tuberculosis is increased after providing health education and developments of useful materials. ${ }^{10}$

The respondents had good knowledge on sign and symptoms of tuberculosis whereas many misunderstanding were found in the route of transmission and diagnostic features of tuberculosis. Concerning the sign and symptoms, the study showed almost all (98\%) said chest pain, cough more than 2 weeks is the sign and symptoms, 47 (94\%) said weight loss of appetite, 45 (90\%) said fever at night and night sweat, tiredness, blood in sputum each and $44(88 \%)$ said that 2 or more than 2 weeks fever is the sign and symptoms. Regarding modes of transmission of the tuberculosis, majority (82\%) said that through infected patient and $39(78 \%)$ said from pregnant mothers. In regard to the detection of the tuberculosis, majority (94\%) of the respondents said that sputum test and chest X-ray helps to detect tuberculosis, $45(90 \%)$ said on the basis of sign and symptoms. Only $5(10 \%)$ respondents had heard about mountex test. Among them, 2 $(4 \%)$ said skin is taken as the sample unit for mountex test as well as 2(4\%) said blood as sample. Whereas similar findings were found in the study conducted by Zhonghua Jie He (2003) in china in which the medical students had many misunderstandings about the treatment and diseases condition. ${ }^{11}$

DOTS program as INH therapy has been an effective method to treat the tuberculosis. The respondents had low level of knowledge regarding treatment by DOTS and they had also less knowledge regarding its duration and availability. All (50) of the respondents said that tuberculosis is curable diseases. More than two third (78\%) knew that the patients should not be admitted in hospital to receive treatment. More than half (56\%) of respondents had heard about DOTS for the treatment of tuberculosis. Among those, 14 (28\%) knew that DOTS is taken for 6-8 months. Regarding the availability of anti-tubercular drugs, 34(68\%) reported that It is found DOTS center at free of cost and $24(48 \%)$ said that it is found in hospitals at free of cost. ${ }^{12}$

Tuberculosis could have been eliminated by effective treatment, vaccinations and public health measures. ${ }^{13}$ The knowledge of the respondents regarding prevention of TB was found to be inadequate. ${ }^{14}$ Almost all $(96 \%)$ knew that there is BCG vaccination against tuberculosis. regarding preventive measure of tuberculosis, almost all
(98\%) said that BCG given at birth, majority (90\%) of respondents said identifying infected person and curing BT DOTS, $88 \%$ said avoiding sharing utensils used by infected person. $20 \%$ said not living with infected person and $4 \%$ talked about other like avoiding smoking and right disposal of infected sputum. Concerning the spread of tuberculosis by the patients who are already on effective treatment, more than one third (34\%) of respondents said 'Yes', $32 \%$ said 'No' and 36\% said 'I don't know'. likewise, regarding the spread of tuberculosis by the patients who have been cured, nearly three fourth (74\%) of respondents said 'No' and 26\% said 'I don't know'. Respondents were asked what happens when the treatment is stopped at the middle course of the treatment period, $96 \%$ (48\%) of the respondents said that diseases will relapse whereas $96 \%$ said that it will be difficult to treat the diseases and similarly $96 \%$ said that patient will die and $2 \%$ said happens nothing.

\section{Conclusion}

The findings reveal that schooling students of developing countries world still do not have adequate knowledge of tuberculosis. Even through majority of students knew that TB is curable diseases but they are unaware about DOTS therapy, its duration and its availability, and the tests performed to detect TB. Many of the students had not heard about Mountex-test. Therefore there is the need of health teaching with necessary teaching and learning aids regarding TB to the school students. The knowledge should be raised through media, various awareness programmers and inclusion of the topics in syllabus of college students through involvement of parents, teachers and health personnel. Proper knowledge about tuberculosis helps to prevent the spread of TB and management of TB through proper treatment.

\section{Acknowledgements}

We would like to express my sincere thanks to principal of white house college, khumaltar, satdobatto, Lalitpur, for his respective permission and support to conduct this study as well as Mr. Umesh Kumar Sah, Monitoring and Evaluation officer of Nepal Anti Tuberculosis Association (NATA) for his support. We are grateful to the staffs of the Nepal Anti Tuberculosis Association, National SAARC TB Center and of National Health Research center for their kind co-operation.

\section{Conflict of interest}

The author declares no conflict of interest.

\section{References}

1. Mandell GL, Bennett JE, Raphael. Mandell, Douglas, and Bennett's principles and practice of infectious diseases. 7th ed. USA: Churchill Livingstone/Elsevier; 2010. 4320 p.

2. Smeltzer C Suzanne, Brenda G Bare, Janice L Hinkle, et al. Brunner and Suddhart's Textbook of Medical-surgical Nursing. 11th ed. India: Wolters and kluwer; 2008.

3. Wei Sheng, Yan Jui, Robert Koch. Tuberculosis. Am J Respir Crit care Med. 2009;180:475-480.

4. Park K. Park's Textbook of preventive and social medicine. 18th ed. India: Banarsidas Bhanot Publishers; 2005. p. 1-4.

5. Department of health and population.

6. HIV and AIDS SAARC Region update 2013.

7. WHO. Global TB control epidemiology strategy financing, published on the occasion of year 2004-SAARC awareness year for TB and HIVI AIDS, 2004. Nepal: SAARC tuberculosis and HIV/AIDS Center; 2013. 
8. STAC. Special document published on the occasion of the year 2004-SAARC awareness year for TB and HIV/AIDS, 2004. Nepal: SAARC Tuberculosis and HIV/AIDS Center; 2004.

9. Tanimowo MO. Knowledge, attitudes and practices regarding tuberculosis among senior secondary school students. East Afr Med J. 1999;76(1):47-50.

10. Kiefer E, Shao T, Carrasquillo O, et al. Knowledge and attitudes of tuberculosis management in san Juan de Lurigancho district of Lima, peru. J Infect Dev Ctries. 2009;3(10):783-788.

11. Bai LQ, Xiao SY, Xie HW, et al. Knowledge and practice regarding tuberculosis among final-year medical students in human, China. Zhinghua Jie He He Xi Za Zhi. 2003;26(8):458-461.
12. Comstock GW, Livesay VT, Woolpert SF. The prognosis of a positive tuberculin reaction in childhood and adolescence. Am J Epidemiol. 1974;99(2):131-138.

13. Joan Slonczewski, Stephanic white. Tuberculosis in children in developing countries. Microbe Wiki. 2009.

14. Orret FA, Shurland SM. Knowledge and awareness of TB among preuniversity students in Trinidad. J Community Health. 2001;26(6):479485 . 